\title{
The Condensation of Salicylaldehydes and Malononitrile Revisited: Synthesis of New Dimeric Chromene Derivatives
}

\author{
Marta Costa, Filipe Areias, Luís Abrunhosa, ${ }^{\dagger}$ Armando Venâncio, ${ }^{\dagger}$ and Fernanda Proença* \\ Centro de Química, Universidade do Minho, Campus de Gualtar, 4710-057 Braga, Portugal \\ fproenca@quimica.uminho.pt
}

Received November 28, 2007

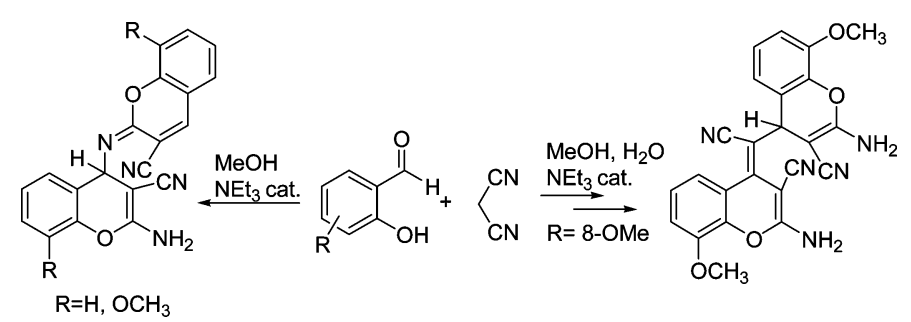

The reaction of salicylic aldehydes with malononitrile was reinvestigated, and the reaction pathway was followed by ${ }^{1} \mathrm{H}$ NMR spectroscopy. A delicate control of the experimental conditions allowed the synthesis of 2-imino- $2 \mathrm{H}$-chromene-3-carbonitriles 1, (2-amino-3-cyano-4H-chromen-4-yl)malononitriles 2, 4-amino5-imino-2,7-dimethoxy-5H-chromeno[3,4-c]pyridine-1-carbonitrile 12, and (4,5-diamino-1-cyano-1,10bdihydro- $2 H$-chromeno[3,4-c]pyridin-2-ylidene)malononitrile 13. Two novel 2-iminochromene dimers, with structures $\mathbf{8}$ and $\mathbf{9}$, were isolated and fully characterized. The activity of compound 8a on Aspergillus spp. growth and on ochratoxin A production was evaluated. The results of the bioassays indicate that compound 8a, applied at concentrations of $2 \mathrm{mM}$, totally inhibited the growth of the fungi tested. Ochratoxin A production by Aspergillus alliaceus was reduced by about $93 \%$ with a $200 \mu \mathrm{M}$ solution of this compound. A moderate inhibitory effect was observed for the analogous structure $\mathbf{8 b}$, and no inhibition was registered for compounds $\mathbf{2}$ and $\mathbf{1}$, used as synthetic precursors of the dimeric species $\mathbf{8}$.

\section{Introduction}

Chromene derivatives are an important class of compounds, widely present in plants, including edible vegetables and fruits. ${ }^{1}$ Numerous bioactive natural products have been identified, and the presence of the chromene-based structure has been associated with the capacity to prevent disease. ${ }^{2}$ Synthetic analogues were developed over the years, some of them displaying remarkable effects as pharmaceuticals, ${ }^{3}$ including antifungal ${ }^{4}$ and antimicrobial activity. ${ }^{5}$

The classic method for the synthesis of 2-iminochromenes is the Knoevenagel condensation of salicylic aldehydes with active methylene compounds, followed by intramolecular cyclization. A detailed analysis of the reports on the reaction of salicylaldehyde and malononitrile ${ }^{6}$ indicates that a delicate

$\dagger \mathrm{BB}-$ Institute for Biotechnology and Bioengineering, Centre for Biological Engineering, Universidade do Minho, Campus de Gualtar 4710-057, Braga, Portugal.

(1) Curini, M.; Cravotto, G.; Epifano, F.; Giannone, G. Curr. Med. Chem. 2006, 13, 199-222.

(2) O'Kennedy, P., Thornes, R. D., Eds. In Coumarins: Biology, Applications and Mode of Action; J. Wiley \& Sons: Chichester, 1997. control of solvent, temperature, and ratio of reagents are determinant for the incorporation of 1,2 , or 3 molar equiv of malononitrile in the aldehyde unit. ${ }^{6 \mathrm{~b}}$ Compounds $\mathbf{1 - 4}$ (Figure 1) were identified as the products of this reaction, formed in the presence of base, at room temperature, either using ethanol $^{6 a-d}$ or water ${ }^{6 e}$ as solvent.

(3) For recent examples of biologically active chromene derivatives, see: (a) Yu, D.; Suzuki, M.; Xie, L.; Morris-Natschke, S. L.; Lee, K.-H. Med. Res. Rev. 2003, 23, 322-345. (b) Khan, K. M.; Saify, Z. S.; Khan, M. Z.; Choudhary, M. I.; Perveen, S.; Chohan, Z. H.; Supuran, C. T.; ZiaUllah; Atta-Ur-Rahman. J. Enz. Inhib. Med Chem. 2004, 19, 373-379. (c) Abd El-Aziz, A. S.; El-Agrody, A. M.; Bedair, A. H.; Corkery, T. C.; Ata, A. Heterocycles 2004, 63, 1793-1812. (d) Borges, F.; Roleira, F.; Milhazes, N.; Santana, L.; Uriarte, E. Curr. Med. Chem. 2005, 12, 887-916. (e) Chimenti, F.; Bizzarri, B.; Bolasco, A.; Secci, D.; Chimenti, P.; Carradori, S.; Granese, A.; Rivanera, D.; Lilli, D.; Scaltrito, M. M.; Brenciaglia, M. I. Eur. J. Med. Chem. 2006, 41, 208-212. (f) Kulkarni, M. V.; Kulkarni, G. M.; Lin, C. H.; Sun, C. M. Curr. Med. Chem. 2006, 13, 2795-2818.

(4) (a) Tangmouo, J. G.; Meli, A. L.; Komguem, J.; Kuete, V.; Ngounou, F. N.; Lontsi, D.; Beng, V. P.; Choudhary, M. I.; Sondengam, B. L. Tetrahedron Letters 2006, 47, 3067-3070. (b) Abd-El-Aziz, A. S.; ElAgrody, A. M.; Bedair, A. H.; Corkery, T. C.; Ata, A. Heterocycles 2004, 63, 1793-1812. (c) Khafagy, M. M.; Abd El-Wahab, A. H. F.; Eid, F. A.; El-Agrody, A. M. Farmaco 2002, 57, 715-722. 
<smiles>N#Cc1cc2ccccc2oc1=N</smiles>

1<smiles>N#CC1=C(N)Oc2ccccc2C1C(C#N)C#N</smiles><smiles>CC(C#N)C1c2ccccc2Oc2nc(N)c(C#N)c(N)c21</smiles>

3

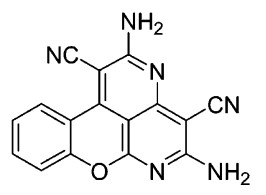

FIGURE 1. Products identified in the reaction of salicylaldehyde and malononitrile.

A recent publication reports the preparation of 2-iminochromene 1 when a 1:1 mixture of the reagents was refluxed in ethanol in the presence of triethylamine. ${ }^{7}$ The ${ }^{1} \mathrm{H}$ NMR spectrum of the product, available in the Supporting Information, indicates that the structure was incorrectly assigned, and it does not correspond to compounds $\mathbf{2}, \mathbf{3}$, or $\mathbf{4}$. In the present work, we carried out a detailed study on the reaction of salicylic aldehydes and malononitrile in an attempt to clarify the reaction pathway, the structure of the isolated products, and the corresponding reaction conditions. The synthetic approaches allowed the preparation of two novel 2-iminochromene dimers. To the best of our knowledge, the formation of these types of chromene dimers has never been reported. Previous work refers a particular type of coumarin dimer that is obtained from photoreaction of coumarin and some derivatives by a $[\pi 2 s+\pi 2 s]$ cycloaddition reaction. ${ }^{8}$ These compounds have attracted considerable interest mainly due to their biological and photobiological importance, and extensive research has been carried out on their regioselective and stereoselective synthesis. ${ }^{9}$ More recently, the photolysis of coumarin-3-carboxylic acid was reported to generate

(5) (a) Kitamura, R. O. S.; Romoff, P.; Young, M. C. M.; Kato, M. J.; Lago, J. H. G. Phytochemistry 2006, 67, 2398-2402. (b) Iqbal, M. C. M.; Jayasinghe, U. L. B.; Herath, H. M. T. B.; Wijesekara, K. B.; Fujimoto, Y. Phytoparasitica 2004, 32, 119-126 (c) Kraus, G. A.; Kim, I. J. Org. Chem. 2003, 68, 4517-4518. (d) Sardari, S.; Nishibe, S.; Daneshtalab, M. Stud. Nat. Prod. Chem. 2000, 23, 335-393. (e) El-Agrody, A. M.; El-Latif, M. S. A.; El-Hady, N. A.; Fakary, A. H.; Bedair, A. H. Molecules 2001, 6, 519-527.

(6) (a) Sakurai, A.; Motomura, Y.; Midorikawa, H. J. Org. Chem. 1972, 37, 1523-1526. (b) O'Callaghan, C. N.; McMurry, T. B. H.; O'Brian, J. E. J. Chem. Soc., Perkin Trans, 1 1995, 417-420. (c) O'Callaghan, C. N.; McMurry, T. B. H.; O'Brian, J. E.; Draper, S. M. J. Chem. Res, Synop. 1997, 312-313; J. Chem. Res., Miniprint 1997, 2101-2122. (d) Volmajer, J.; Toplak, R.; Leban, I.; Le Marechal, A. M. Tetrahedron 2005, 61, 70127021. (e) Fringuelli, F.; Piermatti, O.; Pizzo, F. Synthesis 2003, 15, $2331-$ 2334.

(7) (a) Evdokimov, N. M.; Kireev, A. S.; Yakovenko, A. A.; Antipin, M. Y.; Magedov, I. V.; Kornienko, A. Tetrahedron Lett. 2006, 47, 93099312. (b) Evdokimov, N. M.; Kireev, A. S.; Yakovenko, A. A.; Antipin, M. Y.; Magedov, I. V.; Kornienko, A. J. Org. Chem. 2007, 72, 34433453.

(8) (a) Ciamician, G.; Silber, P. Chem. Ber. 1902, 35, 4128-4131. (b) Anet, R. Can. J. Chem. 1962, 40, 1249-1257. (c) Schenck, G. O.; Vonwilucki, I.; Krauch, C. H. Ber. 1962, 95, 1409-1412. (d) Morrison, H.; Curtis, H.; McDowell, T. J. Am. Chem. Soc. 1966, 88, 5415-5419. (e) Hoffman, R.; Wells, P.; Morrison, H. J. Org. Chem. 1971, 36, 102-108.

(9) For recent work on these dimeric coumarins, see: (a) Yu, X.; Scheller, D.; Rademacher, O.; Wolff, T. J. Org. Chem. 2003, 68, 7386-7399. (b) Zhao, D.; Ding, K. Org. Lett. 2003, 5, 1349-1351. (c) D'Auria, M. Racioppi, R. J. Photochem. Photobiol. 2004, 163, 557-559. (d) Tanaka, K.; Fujiwara, T. Org. Lett. 2005, 7, 1501-1503. (e) Karthikeyan, S.; Ramamurthy, V. J. Org. Chem. 2006, 71, 6409-6413. (f) Zhao, L.; Loy, D. A.; Shea, K. J. J. Am. Chem. Soc. 2006, 128, 14250-14251. the decarboxylated $4,4^{\prime}$-dimer of chroman-2-one. ${ }^{10}$ The activity of one of the dimeric species prepared in the present work and that of the compounds used as synthetic precursors was tested on four Aspergillus spp. growth and on their ability to produce the mycotoxin ochratoxin A.

\section{Results and Discussion}

Salicylaldehyde 5a and substituted salicylaldehydes $\mathbf{5 b}-\mathbf{g}$ were reacted with 2 molar equiv of malononitrile $\mathbf{6}$ under different reaction conditions (Scheme 1, Table 1). The formation of a (2-amino-3-cyano- $4 H$-chromen-yl)malononitrile $\mathbf{2}$ occurred in dichloromethane or in methanol with triethylamine, at room temperature or at $10{ }^{\circ} \mathrm{C}$. Compounds $\mathbf{2} \mathbf{a}-\mathbf{d}, \mathbf{g}$ were isolated in moderate/good yields by this method. The yield and reaction time were considerably improved when the reagents were combined in a $0.05 \mathrm{M}$ aqueous solution of sodium hydrogen carbonate or sodium carbonate, at room temperature, following the procedure described by Pizzo et al. to prepare chromenyl malononitriles $\mathbf{2 a}$ and $\mathbf{2} \mathbf{c}$. ${ }^{\text {e }}$ Under these reaction conditions, compounds 2 were isolated as white solids after 5-40 min.

When the reaction time was extended to $4.5 \mathrm{~h}-1$ day, the 2-iminochromenes $\mathbf{1 a}-\mathbf{g}$ were the only products isolated in excellent yield. The 2-oxochromenes $7 \mathbf{a}-\mathbf{d}$ were also prepared from the reaction of the corresponding aldehydes with malononitrile in the presence of aqueous base, followed by addition of concentrated hydrochloric acid and heating at $80-90{ }^{\circ} \mathrm{C}$. This method was previously used by Pizzo et al. to prepare 2-oxochromenes 7a (90\%) and 7c (85\%). ${ }^{6 e}$

When salicylaldehyde and malononitrile were stirred at room temperature for 2 days, in a $0.05 \mathrm{M}$ aqueous solution of sodium hydrogen carbonate, a different yellow solid was isolated and identified as having the dimeric structure $\mathbf{8}$ (Scheme 1, Table 1). Aldehydes $\mathbf{5 b}, \mathbf{5 c}, \mathbf{5 d}$, and $\mathbf{5 f}$ failed to generate an analogous dimeric product after prolonged stirring in aqueous base, in the presence of malononitrile. The corresponding 2-iminochromene 1 was always the only product isolated. When salicylaldehyde 5a was combined with 2 molar equiv of malononitrile in methanol and triethylamine, compound 8a was also isolated $(84.5 \%)$, after 1 day at room temperature.

The reaction of 3-methoxysalicyladehyde $\mathbf{5 b}$ and malononitrile in methanol and catalysis of triethylamine led to a 2:1 mixture of $\mathbf{1 b}$ and $\mathbf{8 b}$ after 1 day at room temperature. When this mixture was solubilized in a small volume of DMSO and stirred at room temperature, the pure product $\mathbf{8 b}$ started to precipitate after $2 \mathrm{~h}$ at room temperature and was filtered after 21 days $(75.7 \%)$. Under the same reaction conditions, aldehydes $\mathbf{5 c}$ and $\mathbf{5 d}$ led to solid mixtures containing the (2-amino-3-cyano$4 H$-chromen-yl)malononitrile $\mathbf{2}$ and the dimer $\mathbf{8}$, always as the minor component. Aldehydes $\mathbf{5 e}, \mathbf{5 f}$, and $\mathbf{5 g}$ evolved to complex mixtures, with extensive degradation.

The structure assignment for compound $\mathbf{8}$ was based mainly on the ${ }^{1} \mathrm{H}$ and ${ }^{13} \mathrm{C}$ NMR data, supported by correlation techniques (HMQC and HMBC). The proton on $\mathrm{C} 4(\delta 5.85$ $\mathrm{ppm}$ ) showed an intense correlation with $\mathrm{C} 5, \mathrm{C} 8 \mathrm{a}, \mathrm{C} 2$, and $\mathrm{C}^{\prime}$. The proton on $\mathrm{C}^{\prime}$ ( $\left.\delta 8.33 \mathrm{ppm}\right)$ correlated with $\mathrm{C}^{\prime}, \mathrm{C}^{\prime} \mathrm{a}^{\prime}$, and $\mathrm{C}^{\prime}$. This evidence and the fact that the 2-iminochromene 1a slowly evolves to $\mathbf{8 a}$ in DMSO- $d_{6}$ solution strongly supported the structure assignment. The two cyano groups $(\delta 120.42 \mathrm{ppm}$ and $\delta 114.99 \mathrm{ppm}$ in the ${ }^{13} \mathrm{C}$ NMR spectrum) are both visible

(10) Kawata, H.; Ichikawa, S.; Kumagai, T.; Niizuma, S. Tetrahedron Lett. 2002, 43, 5161-5163. 


\section{SCHEME 1}

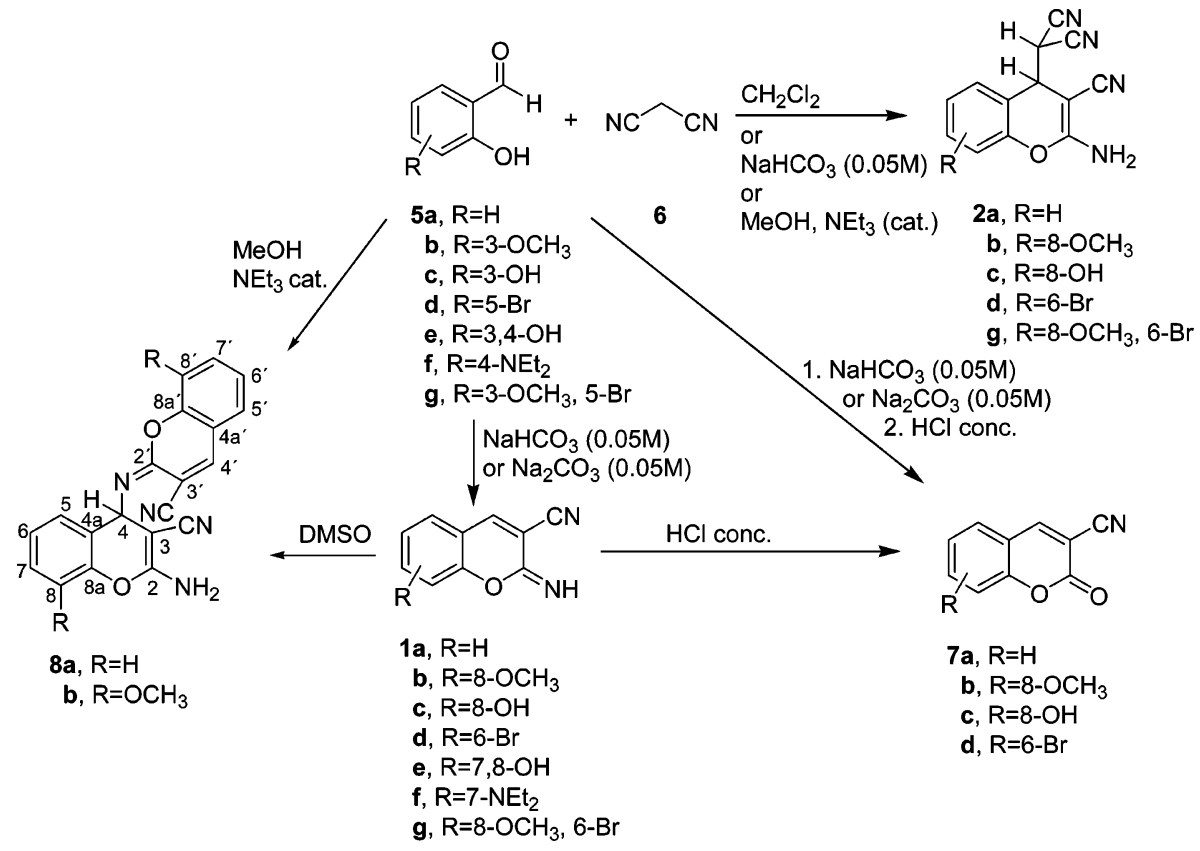

TABLE 1. Reagents and Reaction Conditions for the Synthesis of Compounds 1, 2, and 7 and for Dimers 8 and 9

\begin{tabular}{|c|c|c|}
\hline compd & reaction conditions & $\begin{array}{c}\text { yield } \\
(\%)\end{array}$ \\
\hline \multirow[t]{2}{*}{$1 \mathbf{a}^{a}$} & $\mathbf{5 a}+\mathbf{6}(1: 1$ ratio $), \mathrm{NaHCO}_{3}(0.05 \mathrm{M}), \mathrm{rt}, 7 \mathrm{~h}$ & 86 \\
\hline & $\mathbf{5 a}+\mathbf{6}(1: 1$ ratio $), \mathrm{Na}_{2} \mathrm{CO}_{3}(0.05 \mathrm{M}), \mathrm{rt}, 17 \mathrm{~h}$ & 90 \\
\hline \multirow[t]{2}{*}{$\mathbf{1 b}^{a}$} & $5 \mathbf{b}+\mathbf{6}(1: 1$ ratio $), \mathrm{NaHCO}_{3}(0.05 \mathrm{M}), \mathrm{rt}, 6 \mathrm{~h}$ & 90 \\
\hline & $\mathbf{5 b}+\mathbf{6}(1: 1$ ratio $), \mathrm{Na}_{2} \mathrm{CO}_{3}(0.05 \mathrm{M}), \mathrm{rt}, 3.5 \mathrm{~h}$ & 91 \\
\hline \multirow[t]{2}{*}{$1 c^{b}$} & $\mathbf{5 c}+\mathbf{6}(1: 1$ ratio $), \mathrm{NaHCO}_{3}(0.05 \mathrm{M}), \mathrm{rt}, 4,5 \mathrm{~h}$ & 89 \\
\hline & $\mathbf{5 c}+\mathbf{6}(1: 1$ ratio $), \mathrm{Na}_{2} \mathrm{CO}_{3}(0.05 \mathrm{M}), \mathrm{rt}, 1,5 \mathrm{~h}$ & 70 \\
\hline 1d & $\mathbf{5 d}+\mathbf{6}(1: 1$ ratio $), \mathrm{Na}_{2} \mathrm{CO}_{3}(0.05 \mathrm{M}), \mathrm{rt}, 1$ day & 86 \\
\hline 1e & $5 \mathbf{e}+\mathbf{6}(1: 1$ ratio $), \mathrm{Na}_{2} \mathrm{CO}_{3}(0.05 \mathrm{M}), 0^{\circ} \mathrm{C}, 2 \mathrm{~h}$ & 62 \\
\hline 1f & $\mathbf{5 f}+\mathbf{6}(1: 1$ ratio $), \mathrm{NaHCO}_{3}(0.05 \mathrm{M}), \mathrm{rt}, 20 \mathrm{~h}$ & 88 \\
\hline $1 \mathrm{~g}$ & $5 \mathbf{g}+\mathbf{6}(1: 1$ ratio $), \mathrm{NaHCO}_{3}(0.05 \mathrm{M}), \mathrm{rt}, 22 \mathrm{~h}$ & 100 \\
\hline \multirow[t]{3}{*}{$2 \mathbf{a}^{c}$} & $\begin{array}{l}5 \mathbf{a}+\mathbf{6}(1: 2 \text { ratio }), \text { dichloromethane, } 9^{\circ} \mathrm{C}, \\
1 \text { month }\end{array}$ & 84 \\
\hline & $\begin{array}{l}\mathbf{5 a}+\mathbf{6}\left(1: 2 \text { ratio), dichloromethane, } \mathrm{NEt}_{3}, \mathrm{rt},\right. \\
\quad 11 \mathrm{~h}\end{array}$ & 74 \\
\hline & $\mathbf{5 a}+\mathbf{6}(1: 2$ ratio $), \mathrm{NaHCO}_{3}(0.05 \mathrm{M}), \mathrm{rt}, 40 \mathrm{~min}$ & 91 \\
\hline \multirow[t]{3}{*}{$2 \mathbf{b}^{c}$} & $\begin{array}{l}\mathbf{5 b}+\mathbf{6}(1: 2 \text { ratio }), \mathrm{MeOH}, \mathrm{NEt}_{3}, 0^{\circ} \mathrm{C}, 1.5 \mathrm{~h} ; 9^{\circ} \mathrm{C} \text {, } \\
15.5 \mathrm{~h}\end{array}$ & 94 \\
\hline & $\mathbf{5 b}+\mathbf{6}(1: 2$ ratio $)$, dichloromethane, $\mathrm{NEt}_{3}, \mathrm{rt}, 5 \mathrm{~h}$ & 82 \\
\hline & $\mathbf{5 b}+\mathbf{6}(1: 2$ ratio $), \mathrm{NaHCO}_{3}(0.05 \mathrm{M}), \mathrm{rt}, 8 \mathrm{~min}$ & 100 \\
\hline \multirow[t]{2}{*}{$2 c$} & $\mathbf{5 c}+\mathbf{6}(1: 2$ ratio $)$, dichloromethane, $8{ }^{\circ} \mathrm{C}, 14$ days & 90 \\
\hline & $\mathbf{5 c}+\mathbf{6}(1: 2$ ratio $), \mathrm{NaHCO}_{3}(0.05 \mathrm{M}), \mathrm{rt}, 6 \mathrm{~min}$ & 85 \\
\hline \multirow[t]{3}{*}{ 2d } & $\mathbf{5 d}+\mathbf{6}(1: 2$ ratio $)$, dichloromethane, $8^{\circ} \mathrm{C}, 17$ days & 63 \\
\hline & $\mathbf{5 d}+\mathbf{6}(1: 2$ ratio $)$, dichloromethane, $\mathrm{NEt}_{3}, \mathrm{rt}, 2 \mathrm{~h}$ & 92 \\
\hline & $\mathbf{5 d}+\mathbf{6}(1: 2$ ratio $), \mathrm{NaHCO}_{3}(0.05 \mathrm{M}), \mathrm{rt}, 30 \mathrm{~min}$ & 73 \\
\hline $2 \mathrm{~g}$ & $\mathbf{5 g}+\mathbf{6}(1: 2$ ratio $)$, dichloromethane, $\mathrm{NEt}_{3}, \mathrm{rt}, 4.5 \mathrm{~h}$ & 73 \\
\hline $7 \mathbf{a}^{b}$ & $\begin{array}{l}\text { 1. } 5 \mathbf{a}+\mathbf{6}\left(1: 2 \text { ratio), } \mathrm{Na}_{2} \mathrm{CO}_{3}(0.05 \mathrm{M}), \mathrm{rt}, 16 \mathrm{~h}\right. \\
\text { 2. } \mathrm{HCl} \text { concd } 3.7 \text { equiv, } 80^{\circ} \mathrm{C}, 2 \mathrm{~h}\end{array}$ & 87 \\
\hline $7 b$ & $\begin{array}{l}\text { 1. 5b }+\mathbf{6}(1: 1 \text { ratio }), \mathrm{Na}_{2} \mathrm{CO}_{3}(0.05 \mathrm{M}), \mathrm{rt}, 21 \mathrm{~h} \\
\text { 2. } \mathrm{HCl} \text { concd } 3.7 \text { equiv, } 90^{\circ} \mathrm{C}, 4 \mathrm{~h}\end{array}$ & 100 \\
\hline $7 c^{b}$ & $\begin{array}{l}\text { 1. } \mathbf{5 c}+\mathbf{6}(1: 1 \text { ratio }), \mathrm{Na}_{2} \mathrm{CO}_{3}(0.05 \mathrm{M}), \mathrm{rt}, 2 \mathrm{~h} \\
\text { 2. } \mathrm{HCl} \text { concd } 3.7 \text { equiv, } 80^{\circ} \mathrm{C}, 2.5 \mathrm{~h}\end{array}$ & 84 \\
\hline 7d & $\begin{array}{l}\text { 1. } 5 \mathbf{d}+\mathbf{6}(1: 2 \text { ratio }), \mathrm{Na}_{2} \mathrm{CO}_{3}(0.05 \mathrm{M}), \mathrm{rt}, 12 \mathrm{~h} \\
\text { 2. } \mathrm{HCl} \text { concd } 3.7 \text { equiv, } 80^{\circ} \mathrm{C}, 5.5 \mathrm{~h}\end{array}$ & 90 \\
\hline \multirow[t]{2}{*}{$8 \mathbf{a}$} & $\mathbf{5 a}+\mathbf{6}(1: 2$ ratio $), \mathrm{MeOH}, \mathrm{NEt}_{3}, \mathrm{rt}, 24 \mathrm{~h}$ & 85 \\
\hline & $\mathbf{5 a}+\mathbf{6}(1: 2$ ratio $), \mathrm{NaHCO}_{3} 0.05 \mathrm{M}, \mathrm{rt}, 2$ days & 76 \\
\hline $\mathbf{8 b}$ & $\begin{array}{l}\text { 1. } \mathbf{5 b}+\mathbf{6}(1: 1 \text { ratio }), \mathrm{MeOH}, \mathrm{NEt}_{3}, \mathrm{rt}, 6 \mathrm{~h} \\
\text { 2. DMSO, rt, } 21 \text { days }\end{array}$ & 76 \\
\hline \multirow[t]{2}{*}{9} & $\mathbf{1 b}, \mathrm{MeOH}, \mathrm{H}_{2} \mathrm{O}, \mathrm{NEt}_{3}, \mathrm{rt}, 20 \mathrm{~h}$ & 40 \\
\hline & $\mathbf{2 b}+\mathbf{1 b}(1: 1$ ratio), $\mathrm{NaOH} 1 \mathrm{M}, \mathrm{rt}, 16 \mathrm{~h}$ & 74 \\
\hline
\end{tabular}

in the IR spectrum as a medium $\left(v=2225 \mathrm{~cm}^{-1}\right)$ and an intense $\left(v=2196 \mathrm{~cm}^{-1}\right)$ band, indicating that one of the triple bonds may be conjugated with an electron-donating amino group.

Among the various attempts to improve the yield of dimer $\mathbf{8 b}$, the 2-iminochromene $\mathbf{2} \mathbf{b}$ was solubilized in methanol and water, in the presence of triethylamine, and the mixture was stirred at room temperature for $20 \mathrm{~h}$. A different product was isolated under these experimental conditions. Elemental analysis indicated that the molecule combined two units of 2-iminochromene, where two carbon atoms and one nitrogen were incorporated. This product was isolated as an off-white solid in $41 \%$ yield.

Structure 9, proposed for this compound (Scheme 2), was confirmed by IR and NMR spectroscopy. In the ${ }^{1} \mathrm{H}$ NMR spectrum, apart from the aromatic protons and those assigned to the amino groups $(\delta 7.39$ and $\delta 7.17 \mathrm{ppm})$, only one $\mathrm{C}-\mathrm{H}$ is present $(\delta 4.05 \mathrm{ppm})$. In the HMQC spectrum, all of the carbons located two and three bonds away from this proton could be identified, with the exception of $\mathrm{C}^{\prime}$. The signal for this carbon is not sufficiently intense to be seen in the ${ }^{13} \mathrm{C} N M R$ spectrum, but it is possible to identify its correlation with $\mathrm{C}^{\prime}$ $\mathrm{H}$, at $\delta 115.9 \mathrm{ppm}$. The three cyano groups $(\delta 119.64,117.75$, and $117.53 \mathrm{ppm}$ ) are visible in the IR spectrum as two bands at $v 2200 \mathrm{~cm}^{-1}$ (medium) and $v 2184 \mathrm{~cm}^{-1}$ (intense).

The isolation of compound $\mathbf{9}$ from the 2-iminochromene $\mathbf{1 b}$ suggests that, in the presence of water and base, partial hydrolysis of the starting material occurs to regenerate the aldehyde $\mathbf{5 b}$ and malononitrile (Scheme 2). Addition of malononitrile to $\mathbf{1 b}$ can lead to $\mathbf{2} \mathbf{b}$, which evolves to the stable anion $\mathbf{1 0}$ in basic medium. Addition of $\mathbf{1 0}$ to another molecule of 2-iminochromene $\mathbf{1 b}$ generates an adduct $\mathbf{1 1}$, the precursor of 9 after elimination of $\mathrm{HCN}$. The proton can be removed either from $\mathrm{C} 4$ or $\mathrm{C}^{\prime}$, leading to the same final product. Considering this mechanistic proposal, the experimental conditions were rationalized by combining chromenes $\mathbf{1 b}$ and $\mathbf{2 b}$ in a 1:1 molar ratio, in the presence of aqueous base $(1 \mathrm{M} \mathrm{NaOH})$. After $16 \mathrm{~h}$ at room temperature, compound $\mathbf{9}$ was isolated as an off-white solid, in $74 \%$ yield (Table 1 ). 


\section{SCHEME 2}

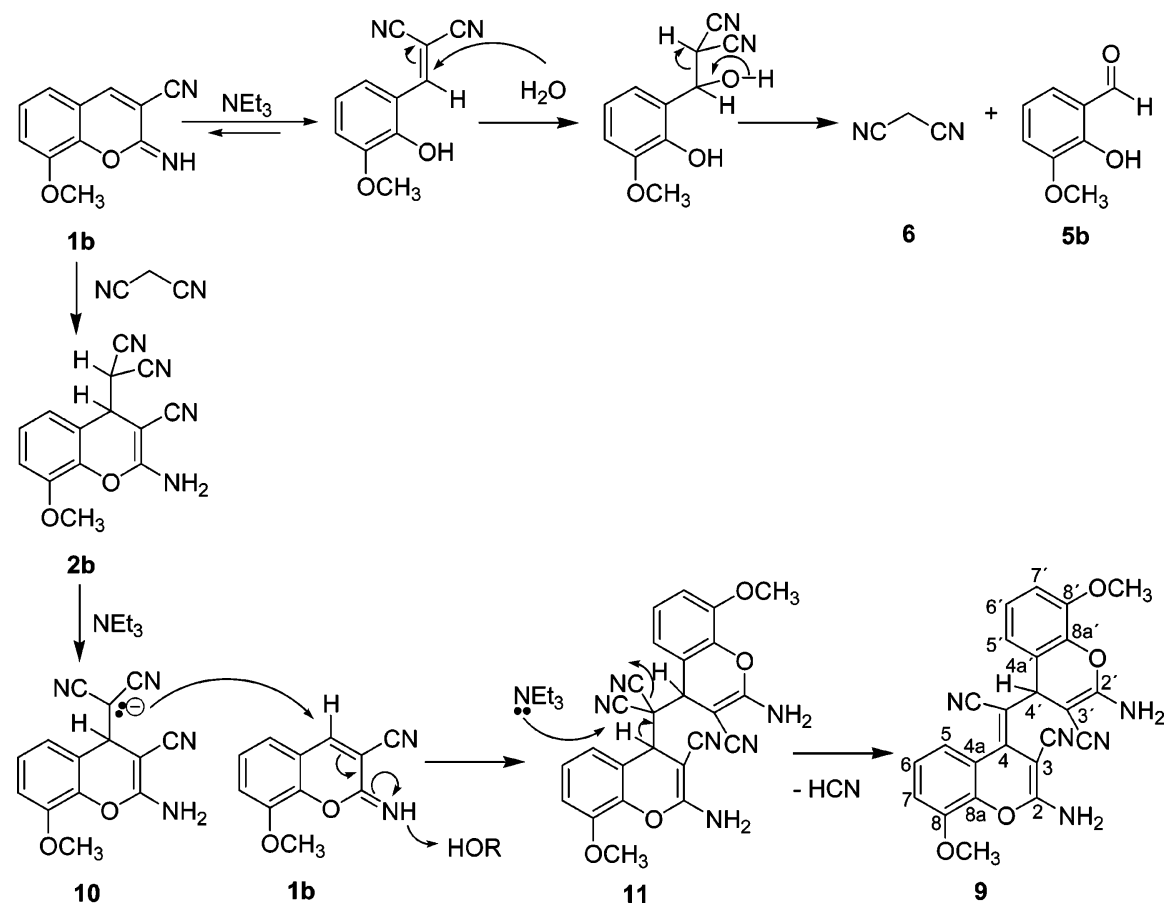

\section{SCHEME 3}<smiles>[R]c1cccc2c1OC(N)=C(C#N)C2C(C#N)C#N</smiles><smiles>[R]c1cccc2c1OC(N)=C1C(N)=NC(=C(C#N)C#N)CC12C#N</smiles>

2b, R=3-OCH c, $\mathrm{R}=3-\mathrm{OH}$ $\mathrm{MeOH}, \mathrm{NEt}_{3}$<smiles>COc1[nH]c(=N)c2c(=N)oc3c(OC)cccc3c2c1C#N</smiles><smiles>COc1ccc2c(c1C#N)C(=N)Oc1c(OC)nc(N)c(c1C)C2</smiles>

$12 \mathrm{~b}$

When similar experimental conditions were applied to a mixture of chromenes $\mathbf{1 a}, \mathbf{1 c}$, or $\mathbf{1 d}$ with $\mathbf{2 a}, \mathbf{2 c}$, and $\mathbf{2 d}$, respectively, complex mixtures were formed, except from the combination of $\mathbf{1 a}$ and $\mathbf{2} \mathbf{a}$, which evolved to the dimeric structure 8a, after 1 day at room temperature, using $0.05 \mathrm{M}$ aqueous solution of $\mathrm{NaHCO}_{3}$ and triethylamine.

When $\mathbf{2 b}$ was reacted with the corresponding aldehyde $\mathbf{5 b}$ in methanol and triethylamine at $10{ }^{\circ} \mathrm{C}$, the yellow solid that precipitated from the reaction mixture and was filtered after 36 $\mathrm{h}$ proved to be a mixture of aldehyde $\mathbf{5 b}$, dimer $\mathbf{8 b}$, and 2-iminochromene $\mathbf{1 b}$ in a 4:1:20 ratio. This result indicates that methanol is not involved in the reaction pathway that leads to structure 9.

Further studies on the reaction of (2-aminochromene-4-yl)malononitrile $\mathbf{2 b}$ with nucleophiles (methanol and triethylamine or malononitrile in THF) resulted in the formation of products 12 and 13, respectively (Scheme 3, Table 2). Compound 13a was actually prepared and reported in a recent publication, ${ }^{7}$ according to the ${ }^{1} \mathrm{H}$ NMR spectrum disclosed in the Supporting
TABLE 2. Reagents and Reaction Conditions for the Synthesis of Compounds 12 and 13

\begin{tabular}{clc}
\hline compd & \multicolumn{1}{c}{ reaction conditions } & yield $(\%)$ \\
\hline 12b & 2b, $\mathrm{MeOH}_{1} \mathrm{NEt}_{3}(1$ drop $), 9^{\circ} \mathrm{C}, 5$ days & 26 \\
& 2b, $\mathrm{MeOH}_{\mathrm{NEt}_{3}(1 \mathrm{drop}), \text { reflux, 3.5 h }}$ & 34 \\
13b & $\mathbf{1 b}+\mathbf{2 b}(1$ equiv $), \mathrm{THF}$, reflux, 3.5 days & 56 \\
13c & $\mathbf{1 c}+\mathbf{2 c}(1$ equiv), THF, reflux, 2 days & 86 \\
\hline
\end{tabular}

Information but was erroneously identified and used as the 2-iminochromene 1a.

The structure of compound $\mathbf{1 3}$ was confirmed by ${ }^{1} \mathrm{H}$ and ${ }^{13} \mathrm{C}$ NMR, where the protons on $\mathrm{C} 1$ (ca. $\delta 4.8 \mathrm{ppm}$ ) and $\mathrm{C} 10 \mathrm{~b}$ (ca. $\delta 4.9 \mathrm{ppm})$ are doublets $(J=4.1 \mathrm{~Hz})$ and the chemical shifts for the adjacent carbon atoms $(\delta 30.3$ and $34.8 \mathrm{ppm}$, respectively) confirm their $\mathrm{sp}^{3}$ nature. The three cyano groups are visible in the ${ }^{13} \mathrm{C}$ NMR $(\delta 112.9,113.4$, and $116.3 \mathrm{ppm})$, and the two amino groups are clearly present in the ${ }^{1} \mathrm{H}$ NMR as two singlets in the $\delta 6.0-7.0 \mathrm{ppm}$ region. In the HMBC spectrum, the protons on $\mathrm{C} 1$ and $\mathrm{C} 10$ allowed the identification of all the carbon atoms, which are two and three bonds away from these protons.

Both reactions are initiated by nucleophilic attack on one of the cyano groups of the malonyl substituent on $\mathrm{C} 4$ of the chromene ring (Scheme 4). Intramolecular cyclization by nucleophilic attack of the newly generated imino nitrogen to the cyano substituent on C3 leads to an intermediate 14 that either tautomerizes to the isolated product $\mathbf{1 3}$ (Nuc = malononitrile) or is oxidized to generate product $\mathbf{1 2}$ ( Nuc = methanol). In the NMR tube (DMSO- $d_{6}$ solution), compound $\mathbf{1 2 b}$ evolves to structure $15 \mathbf{b}$, regenerating the cyano and the phenolic hydroxyl groups.

The synthesis of compounds analogous to $\mathbf{1 5}$ was reported in the literature, when nonphenolic aldehydes were reacted with malononitrile. ${ }^{11}$ The proposed mechanism involved Michael addition of the dicyanomethyl anion to the initially formed arylidenemalononitrile. Nucleophilic attack of methanol to one of the cyano carbon atoms generates the imidate function, 

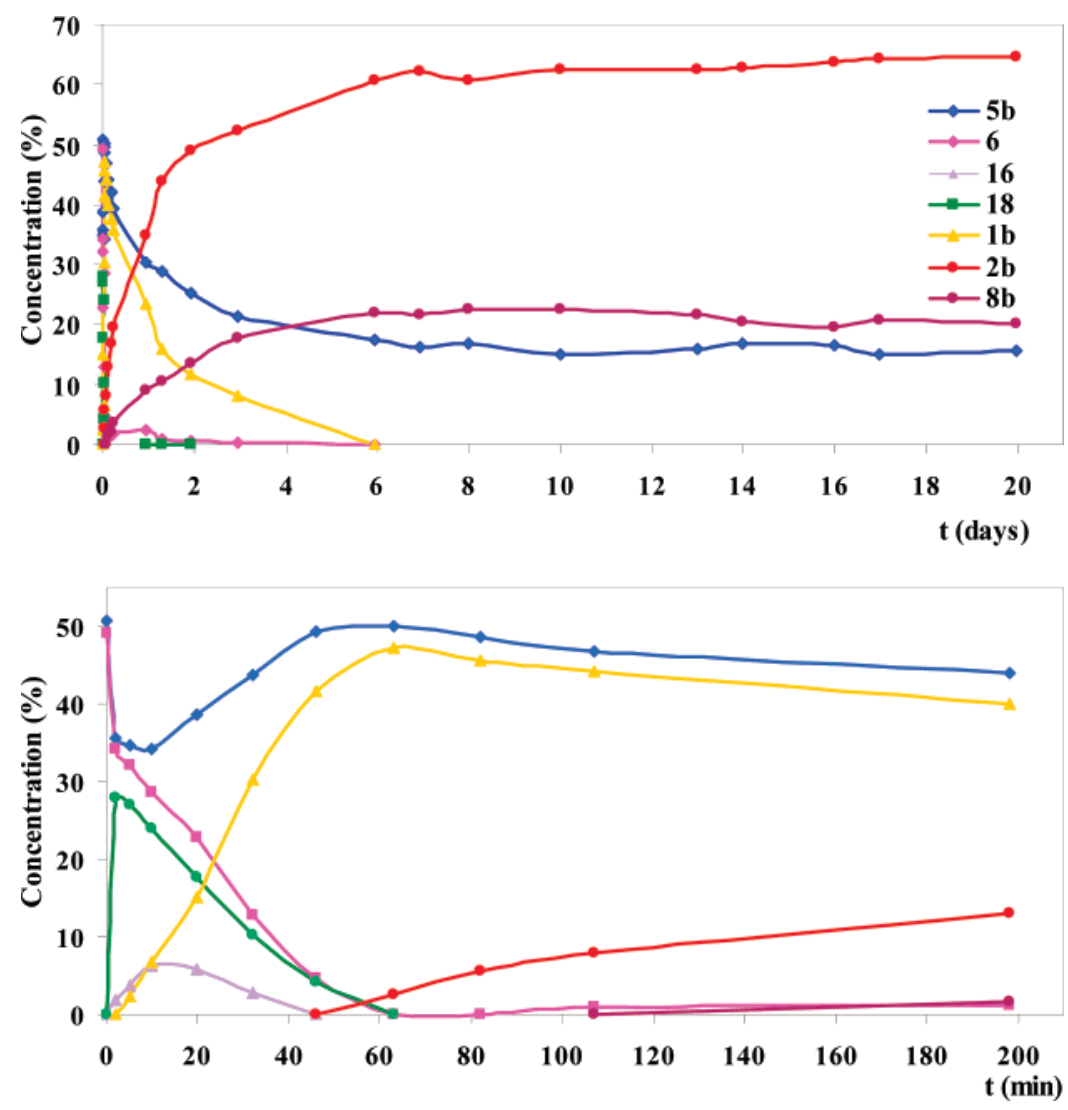

FIGURE 2. ${ }^{1} \mathrm{H}$ NMR study of the evolution, with time, of a solution of 3-methoxysalicylaldehyde (15.1 mmol) and malononitrile (8.6 mmol) in DMSO- $d_{6}(650 \mu \mathrm{L})$ at $20^{\circ} \mathrm{C}$.

\section{SCHEME 4}

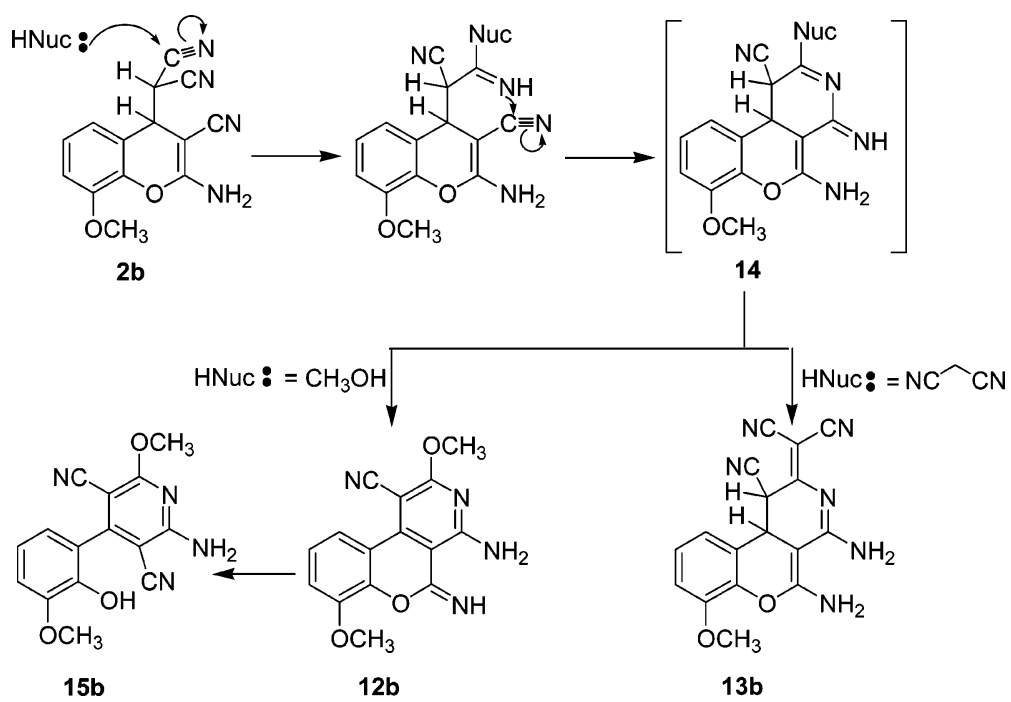

responsible for the intramolecular cyclization that leads to the pyridine ring. To our knowledge, malononitrile was never incorporated in the pyridine ring by this method. Substituted pyridines analogous to compound $\mathbf{1 3}$ were prepared from 2-amino-6-halo-3,5-dicyanopyridines, upon substitution of the halogen atom by malononitrile. ${ }^{12}$

(11) (a) Freeman, F. Chem. Rev. 1969, 69, 591-624. (b) Alvarez-Insua, A.; Lora-Tamayo, M.; Soto, J. J. Heterocycl. Chem. 1970, 7, 1305-1309. (c) Quintela, J.; Peinador, C.; Botana, L.; Estévez, M.; Riguera, R. Bioorg. Med. Chem. 1997, 5, 1543-1553.
Mechanistic Study of the Reaction of 3-MethoxysalicylaIdehyde 5b and Malononitrile 6 by ${ }^{1} \mathrm{H}$ NMR Spectroscopy. Considering that the reaction of malononitrile with 3-methoxysalicylaldehyde $\mathbf{5 b}$ was a rather slow process, the evolution was studied by ${ }^{1} \mathrm{H}$ NMR spectroscopy, using DMSO- $d_{6}$ as solvent. In this experiment, malononitrile $(8.6 \mathrm{mmol})$ was combined with 3-methoxysalicylaldehyde $(15.1 \mathrm{mmol})$ in DMSO- $d_{6}(650 \mu \mathrm{L})$, and the evolution was followed over a

(12) Little, E.; Middleton, W.; Coffman, D.; Engelhardt, V.; Sansen, G. Synthesis 1984, 159-160. 
SCHEME 5. Mechanism for the Reaction of 3-Methoxysalicylaldehyde and Malononitrile in DMSO- $d_{6}$ Solution, According to the ${ }^{1}$ H NMR Study

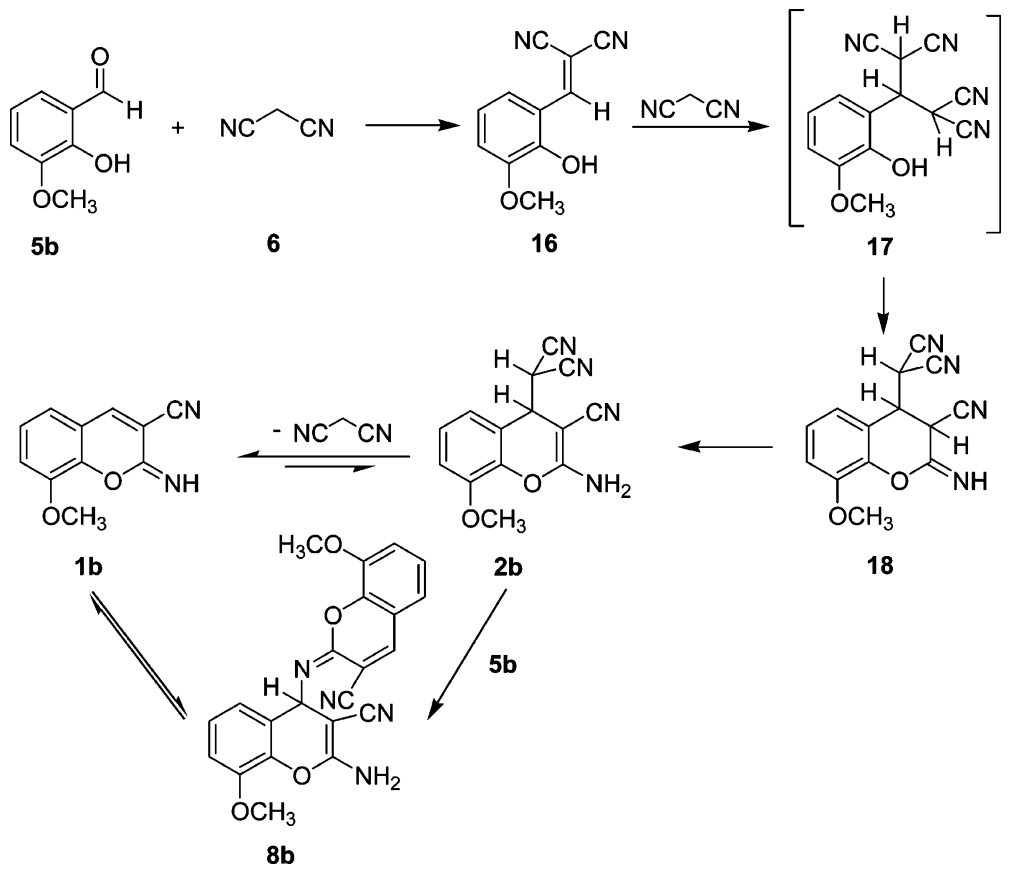

period of 20 days at $20^{\circ} \mathrm{C}$ (Figure 2). A selection of ${ }^{1} \mathrm{H}$ NMR spectra in the interval from $\delta 4.3-10.3 \mathrm{ppm}$ is presented in the Supporting Information.

The first spectrum, run after 2 min, showed the presence of two new compounds, apart from the aldehyde $\mathbf{5 b}$ (35.7\%) and malononitrile $6(34.3 \%)$. One of the compounds was identified as $16(2 \%)$ from a sharp singlet at $\delta 8.44 \mathrm{ppm}$ assigned to the $\mathrm{C}-\mathrm{H}$ proton and a singlet at $\delta 3.84 \mathrm{ppm}$, integrating for three protons and assigned to the methoxyl substituent of the aromatic ring. Structure $\mathbf{1 8}$ was assigned to the other compound (28\%) mainly considering the presence of three $\mathrm{C}-\mathrm{H}$ protons at $\delta 4.93$ ppm $(\mathrm{d} ; J=3.6 \mathrm{~Hz}), \delta 5.33 \mathrm{ppm}\left(\mathrm{dd} ; J_{1}=3.9 \mathrm{~Hz}, J_{2}=5.1\right.$ $\mathrm{Hz})$, and $\delta 6.78 \mathrm{ppm}(\mathrm{d} ; J=5.1 \mathrm{~Hz})$ and one acidic $\mathrm{N}-\mathrm{H}$ at $\delta$ $9.24 \mathrm{ppm}$.

Compound $\mathbf{2 b}(2.3 \%)$ was identified in the reaction mixture after $5 \mathrm{~min}$, and after $45 \mathrm{~min}$, traces of chromene $\mathbf{1 b}$ were also detected by comparison with the ${ }^{1} \mathrm{H}$ NMR spectrum of authentic samples, isolated and fully characterized.

After this time (45 min), only a trace amount of $\mathbf{1 6}$ existed in a mixture containing $\mathbf{5 b}(49.5 \%)$, malononitrile $\mathbf{6}(4.7 \%), \mathbf{1 8}$ (4.3\%), and 1b (41.6\%).

After $1 \mathrm{~h}$, malononitrile was totally consumed, and the only components of the reaction mixture were the aldehyde $\mathbf{5 b}$ $(50.1 \%), \mathbf{2 b}(47.2 \%)$, and the chromene $\mathbf{1 b}(2.7 \%)$.

After approximately $2 \mathrm{~h}$, as the amount of imine $\mathbf{1 b}$ increased $(8.0 \%)$, the presence of malononitrile was detected again $(0.8 \%)$ together with traces of the dimeric species $\mathbf{8 b}$.

The amount of imine $\mathbf{1 b}$ and dimer $\mathbf{8 b}$ gradually increased while the aldehyde $\mathbf{5 b}$ and $\mathbf{2 b} / \mathbf{1 b}$ were consumed. The amount of malononitrile also increased slightly, leading to a maximum of $2.3 \%$ after $23 \mathrm{~h}$.

A slow evolution resulted in the exclusive formation of $\mathbf{1 b}$ (ca. $62 \%$ ) and $\mathbf{8 b}$ (ca. 22\%) after 6 days. 4-Methoxysalicylaldehyde (ca. 16\%) was also present in solution, considering that an excess of this reagent was used.
The reaction mixture was monitored by ${ }^{1} \mathrm{H}$ NMR for the next 20 days, with no significant change in the ratio of these compounds.

In a separate experiment, 2-iminochromene $\mathbf{1 b}(20 \mathrm{mg})$ was solubilized in DMSO- $d_{6}(650 \mu \mathrm{L})$ and the ${ }^{1} \mathrm{H}$ NMR spectrum was acquired immediately after the solubilization, showing that 1b was the only product present in solution. After $16 \mathrm{~h}$ at 19 ${ }^{\circ} \mathrm{C}$, this compound evolved to generate $33 \%$ of dimer $\mathbf{8 b}$.

Conversely, when the dimer $\mathbf{8 b}(20 \mathrm{mg})$ was solubilized in DMSO- $d_{6}(650 \mu \mathrm{L})$, the ${ }^{1} \mathrm{H}$ NMR spectrum showed that $12 \%$ of the chromene $\mathbf{1 b}$ had been formed after $5 \mathrm{~min}$ at $19^{\circ} \mathrm{C}$. After $15 \mathrm{~h}, 87 \%$ of 2 -iminochromene $\mathbf{1 b}$ was present and only $13 \%$ of dimer $\mathbf{8 b}$ remained in solution.

When the same experiment was carried out from the 2-iminochromene 1a (20 mg in $650 \mu \mathrm{L}$ of DMSO- $\left.d_{6}\right)$, the ${ }^{1} \mathrm{H}$ NMR spectrum indicated that, upon solubilization, $15 \%$ of the corresponding dimer $\mathbf{8 a}$ had already been formed. After $3 \mathrm{~h}$, the monomer 1a and dimer 8a were present in a 6:4 ratio. This ratio was not altered after 1 month in the NMR tube.

The ${ }^{1} \mathrm{H}$ NMR spectrum of dimer 8a in DMSO- $d_{6}$ solution indicated that only $7 \%$ of the monomer was present after $3 \mathrm{~h}$ at $19{ }^{\circ} \mathrm{C}$.

These observations allowed us to propose a mechanistic pathway for the reaction of salicylaldehyde and malononitrile (Scheme 5). They also indicate that, in DMSO- $d_{6}$ solution, both the dimer and the monomer species are present as an equilibrium mixture and the stability of compound $\mathbf{1 b}$ is higher than that of $\mathbf{8 b .}$

Attempts to prepare similar dimeric structures from substituted aldehydes $\mathbf{5 c}-\mathbf{g}$ using methanol and triethylamine catalysis failed, as 2-iminochromene $\mathbf{1}$ was the only product that precipitated from solution and was isolated.

\section{Biological Assay}

The antifungal activity of compounds $\mathbf{2 a}, \mathbf{b}, \mathbf{1 a}, \mathbf{b}$, and $\mathbf{8 a}, \mathbf{b}$ on Asperillus spp. growth and on ochratoxin A production was 
TABLE 3. Radial Growth Rates $\left(\mathrm{cm} \mathrm{day}^{-1}\right)$ Inhibition (\%) of Tested Strains in Culture Medium Supplemented with 8a and 8b

\begin{tabular}{crrrrr}
\hline & & \multicolumn{4}{c}{ radial growth rate inhibition ${ }^{a}(\%)$} \\
\cline { 3 - 6 } compd & $\mu$ mol L $^{-1}$ & $\begin{array}{c}\text { A. } \\
\text { alliaceus }\end{array}$ & $\begin{array}{c}\text { A. } \\
\text { carbonarius }\end{array}$ & $\begin{array}{c}\text { A. } \\
\text { niger }\end{array}$ & $\begin{array}{c}\text { A. } \\
\text { ochraceus }\end{array}$ \\
\hline 8a & 50 & 50 & 2 & 41 & 8 \\
& 100 & 51 & 11 & 47 & 13 \\
& 200 & 70 & 23 & 50 & 26 \\
8b & 2000 & 100 & 100 & 100 & 100 \\
& 50 & 2 & 2 & 5 & 3 \\
& 100 & 3 & 0 & 6 & 3 \\
& 200 & 1 & 4 & 14 & 8
\end{tabular}

${ }^{a}$ Values are the mean of three replicates of each.

evaluated. Four Aspergillus species were selected, one strain of each, from the Micoteca da Universidade do Minho (MUM) culture collection, A. alliaceus, A. carbonarius, and A. ochraceus OTA-producing strains, and an A. niger strain not ochratoxigenic. ${ }^{13 a}$ Fungal growth was monitored by the poisoned food technique, using YES medium (2\% yeast extract from Difco, $15 \%$ sucrose, and $2 \%$ agar). Ochratoxion A (OTA) production was evaluated after extraction with methanol and HPLC analyses. ${ }^{13 \mathrm{~b}}$

The results of the bioassays, summarized in Table 3, indicate that compound 8a, applied at concentrations of $2 \mathrm{mM}$, totally inhibited the growth of all tested strains. Ochratoxin A production by A. alliaceus was reduced by around $93 \%$ with a 200 $\mu \mathrm{M}$ solution of this compound. The analogous structure $\mathbf{8 b}$ showed a residual inhibitory effect, while no inhibition was registered for the corresponding compounds $\mathbf{2}$ and $\mathbf{1}$, used as synthetic precursors of the dimeric species $\mathbf{8}$ (data not shown).

The poor activity registered for compound $\mathbf{8 b}$ may be associated with its instability in dilute solution, as was confirmed by the ${ }^{1} \mathrm{H}$ NMR studies. The rapid evolution to the monomer 1b led to an equilibrium mixture where this compound (with no antifungal activity) was the major component. The formation of aggregates has been considered responsible for the antifungal activity of well-known commercial drugs like miconazole and econazole. ${ }^{14}$ The present work reports what can be considered a similar situation, as the only active species is the molecule that results from the association of two monomeric units of 2-iminochromene, linked by a covalent bond.

\section{Conclusion}

The reaction of salicylaldehydes with malononitrile, previously reported in the literature, leads to the formation of (2amino-3-cyano- $4 H$-chromen-yl)malononitriles 2 or 2-imino- $2 H$ chromene-3-carbonitriles $\mathbf{1}$, depending on the reaction conditions. A mild and eco-friendly approach, using aqueous base, allowed the high-yielding synthesis of both compounds $\mathbf{2}$ and $\mathbf{1}$.

It is evident that great care should be taken to control the reaction conditions, as slight modifications in solvent, base, temperature, and/or reaction time can led to the formation of different products. Compound $\mathbf{2 b}$ was further reacted with malononitrile or with methanol and triethylamine to generate the corresponding adducts $\mathbf{1 3}$ and $\mathbf{1 2}$.

Two different dimeric structures $\mathbf{8}$ and $\mathbf{9}$ were isolated in high yield, depending basically on the substituents present in the salicylaldehyde ring $(\mathrm{R}=\mathrm{H}, 3-\mathrm{OMe})$.

(13) (a) Serra, R.; Braga, A.; Venâncio, A. Res. Microbiol. 2005, 156, 515-521. (b) Abrunhosa, L.; Serra, R.; Venâncio, A. J. Agric. Food Chem. 2002, 50, 7493-7496.

(14) Seidler, J.; McGovern, S. L.; Doman, T. N.; Shoichet, B. K. J. Med. Chem. 2003, 46, 4477-4486.
Compound 8a presented significant antifungal activity, when tested on strains of A. alliaceus, A. carbonarius, A. niger, and A. ochraceus. None of the synthetic precursors $\mathbf{2 a}$ or $\mathbf{1 a}$ were active in the same concentration ranges.

\section{Experimental Section}

General Procedure for the Synthesis of Substituted 2-Imino2H-chromene-3-carbonitriles 1.<smiles>[R]c1cccc2cc(C#N)c(=N)oc12</smiles>

Malononitrile (1 molar equiv) was added to a solution of the aldehyde $(0.4 \mathrm{mmol})$ in aqueous $0.05 \mathrm{M} \mathrm{NaHCO}_{3}$ or $0.05 \mathrm{M} \mathrm{Na}_{2}-$ $\mathrm{CO}_{3}(1.5 \mathrm{~mL})$, and the mixture was stirred at room temperature. Within $5 \mathrm{~min}$, a yellow solid started to precipitate from the reaction mixture, which was stirred at room temperature for a further 4.5 to $22 \mathrm{~h}$ (when $\mathrm{NaHCO}_{3}$ was added) or $2-24 \mathrm{~h}$ (when $\mathrm{Na}_{2} \mathrm{CO}_{3}$ was used). The yellow solid was filtered and washed with water and diethyl ether leading to the pure product $\mathbf{1}$.

6-Bromo-2-imino-8-methoxy-2H-chromene-3-carbonitrile 1g: yellow solid; yield $100 \%\left(\mathrm{NaHCO}_{3}\right)$; mp 201-203 ${ }^{\circ} \mathrm{C} ;{ }^{1} \mathrm{H}$ NMR $\left(300 \mathrm{MHz}, \mathrm{DMSO}-d_{6}\right) \delta 3.88(\mathrm{~s}, 3 \mathrm{H}), 7.33(\mathrm{~d}, J=2.1 \mathrm{~Hz}, 1 \mathrm{H})$, $7.43(\mathrm{~d}, J=2.1 \mathrm{~Hz}, 1 \mathrm{H}), 8.25(\mathrm{~d}, J=1.8 \mathrm{~Hz}, 1 \mathrm{H}), 9,07(\mathrm{~d}, J=$ $1.5 \mathrm{~Hz}, 1 \mathrm{H}) ;{ }^{13} \mathrm{C}$ NMR $\left(75 \mathrm{MHz}, \mathrm{DMSO}-d_{6}\right) \delta 56.5,105.7,114.9$, 115.3, 119.0, 122.3, 137.7, 142.4, 145.8, 147.0, 150.4; IR (Nujol mull) 2230, 1653, 1602, 1567. Anal. Calcd for $\mathrm{C}_{11} \mathrm{H}_{7} \mathrm{~N}_{2} \mathrm{O}_{2} \mathrm{Br}$. $0.2 \mathrm{H}_{2} \mathrm{O}: \mathrm{C}, 46.71 ; \mathrm{H}, 2.62 ; \mathrm{N}, 9.91$. Found: $\mathrm{C}, 46.70 ; \mathrm{H}, 2.55 ; \mathrm{N}$, 10.22 .

General Procedure for the Synthesis of Substituted (2-Amino3-cyano-4H-chromene-4-yl)malononitrile 2.<smiles>[R]c1ccc2c(c1)OC(N)=C(C#N)C2C(C#N)(C#N)C#N</smiles>

Method A. Malononitrile (1.7-2 molar equiv) was added to a solution of the aldehyde $(0.4 \mathrm{mmol})$ in dichloromethane $(1.5 \mathrm{~mL})$ (2a,c,d) or dichloromethane $(1.5 \mathrm{~mL})$ and triethylamine $(0.3 \mathrm{~mL})$ $(\mathbf{2 a}, \mathbf{b}, \mathbf{d}, \mathbf{g})$ or methanol $(1.5 \mathrm{~mL})$ in the presence of triethylamine $(0.3 \mathrm{~mL})(\mathbf{2 b})$. The mixture was stirred at $8-9{ }^{\circ} \mathrm{C}$ or at room temperature. The product precipitated from the reaction mixture and was filtered and washed with diethyl ether after 14 days to 1 month (dichloromethane) or 2-11 h (dichloromethane and triethylamine) or $17 \mathrm{~h}$ (methanol and triethylamine). The isolated product was identified as the chromene 2 .

Method B. Malononitrile (1.7-2 molar equiv) was added to a solution of the aldehyde in aqueous $\mathrm{NaHCO}_{3}(0.05 \mathrm{M})$, and the mixture was stirred at room temperature. The product immediately precipitated from the reaction mixture and was filtered and washed with water and diethyl ether after 5-40 min. The product was identified as the chromene 2 .

(2-Amino-3-cyano-8-hydroxy-4H-chromene-4-yl)malononitrile 2c: white solid; yield $90 \%$ (method A, dichloromethane) or $85 \%$ (method B); mp $168-169{ }^{\circ} \mathrm{C} ;{ }^{1} \mathrm{H}$ NMR (300 MHz, DMSO$\left.d_{6}\right) \delta 4.50(\mathrm{~d}, J=3.9 \mathrm{~Hz}, 1 \mathrm{H}), 5.00(\mathrm{~d}, J=3.9 \mathrm{~Hz}, 1 \mathrm{H}), 6.84(\mathrm{dd}$, $J=7.8 \mathrm{~Hz}, 1.2 \mathrm{~Hz}, 1 \mathrm{H}), 6.92(\mathrm{dd}, J=8.1 \mathrm{~Hz}, 1.5 \mathrm{~Hz}, 1 \mathrm{H}), 7.03$ $(\mathrm{t}, J=8.1 \mathrm{~Hz}, 1 \mathrm{H}), 7.38(\mathrm{~s}, 2 \mathrm{H}), 9.99(\mathrm{~s}, 1 \mathrm{H}) ;{ }^{13} \mathrm{C} \mathrm{NMR}(75 \mathrm{MHz}$, DMSO- $\left.d_{6}\right) \delta 32.3,37.4,48.9,113.0,113.1,116.4,118.1,119.1$, 119.5, 124.8, 138.4, 145.3, 163.5; IR (Nujol mull) 2261, 2192, 2142, 1647, 1618, $1584 \mathrm{~cm}^{-1}$. Anal. Calcd for $\mathrm{C}_{13} \mathrm{H}_{8} \mathrm{~N}_{4} \mathrm{O}_{2} \cdot 0.1 \mathrm{H}_{2} \mathrm{O}: \mathrm{C}$, 61.46; H, 3.23; N, 22.06. Found: C, 61.62; H, 3.65; N, 22.25.

General Procedure for the Synthesis of Substituted 2-Oxo2H-chromene-3-carbonitriles 7. 
<smiles>[R]c1ccc2cc(C#N)c(=O)oc2c1</smiles>

Malononitrile ( 1 to 2 molar equiv) was added to a solution of the aldehyde $(0.4 \mathrm{mmol})$ in aqueous $0.05 \mathrm{M} \mathrm{Na}_{2} \mathrm{CO}_{3}(1.5 \mathrm{~mL})$, and the mixture was stirred at room temperature. Within $5 \mathrm{~min}$, a yellow solid started to precipitate from the reaction mixture, which was stirred at room temperature. After $2-21 \mathrm{~h}$, concd $\mathrm{HCl}$ (3.7 molar equiv) was added to the yellow suspension. The reaction mixture was heated at $80-90{ }^{\circ} \mathrm{C}$ for 2 to $5.5 \mathrm{~h}$. The suspension was cooled to room temperature in an ice bath, and the yellow solid was filtered and washed with water and diethyl ether leading to the pure product 7.

2-Oxo-8-methoxy-2H-chromene-3-carbonitrile 7b: yellow solid; yield 100\%; mp 230-232 ${ }^{\circ} \mathrm{C} ;{ }^{1} \mathrm{H}$ NMR $\left(300 \mathrm{MHz}\right.$, DMSO- $\left.d_{6}\right) \delta$ 3.92 (s, 3H), 7.32 (dd, $J=7.8 \mathrm{~Hz}, 1.8 \mathrm{~Hz}, 1 \mathrm{H}), 7.36(\mathrm{t}, J=7.8$ $\mathrm{Hz}, 1 \mathrm{H}), 7.49$ (dd, $J=8.0 \mathrm{~Hz}, 1.8 \mathrm{~Hz}, 1 \mathrm{H}), 8.92(\mathrm{~s}, 1 \mathrm{H}) ;{ }^{13} \mathrm{C} \mathrm{NMR}$ $\left(75 \mathrm{MHz}, \mathrm{DMSO}-d_{6}\right) \delta 56.3,102.4,114.6,117.5,118.0,120.8$, 125.5, 143.4, 146.5, 153.7, 156.6; IR (Nujol mull) 2231, 1713, 1607, 1573. Anal. Calcd for $\mathrm{C}_{11} \mathrm{H}_{7} \mathrm{NO}_{3}$ : C, 65.67; H, 3.48; N, 6.97 . Found: C, 65.85; H, 3.76; N, 7.13.

Synthesis of 2-Amino-4[(3-cyano-2H-chromen-2-ylidene)amino]-2H-chromene-3-carbonitrile $8 \mathrm{a}$.

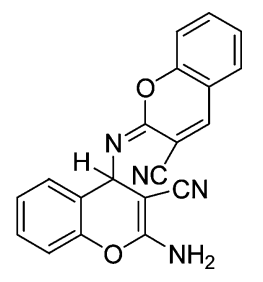

Method A. Malononitrile $(0.39 \mathrm{~g}, 5.90 \mathrm{mmol})$ was added to a mixture of salicylaldehyde $(0.71 \mathrm{~g}, 5.79 \mathrm{mmol})$ in methanol $(3 \mathrm{~mL})$, in the presence of 1 drop of triethylamine. The colorless solution immediately turned yellow and was stirred at room temperature. After 5 min, a yellow solid precipitated from the solution, which was stirred at room temperature for 1 day. The solid was filtered, washed with diethyl ether, and identified as the dimeric species 8a (0.85 g; $2.50 \mathrm{mmol} ; 86 \%)$.

Method B. Salicylaldehyde $(0.61 \mathrm{~g}, 4.97 \mathrm{mmol})$ was added to a solution of (2-amino-3-cyano-4H-chromen-4-yl)malononitrile 2a $(0.20 \mathrm{~g}, 0.86 \mathrm{mmol})$ in ethanol $(3 \mathrm{~mL})$. The mixture was stirred at room temperature for 7 days, while a yellow solid gradually precipitated from the reaction mixture.

The solid was filtered, washed with ethanol, and identified as the title compound $(0.20 \mathrm{~g}, 0.59 \mathrm{mmol}, 68.6 \%)$ : $\mathrm{mp} 165-168$ ${ }^{\circ} \mathrm{C} ;{ }^{1} \mathrm{H}$ NMR (300 MHz, DMSO- $\left.d_{6}\right) \delta 5.85(\mathrm{~s}, 1 \mathrm{H}), 7.05-7.20(\mathrm{~m}$, 4H), 7.25-7.40 (m, 4H), 7.55-7.70 (m, 2H), 8.33(s, 1H); ${ }^{13} \mathrm{C} \mathrm{NMR}$ (75 MHz, DMSO- $\left.d_{6}\right) \delta 48.5,54.9,104.5,115.0,115.5,116.0,117.5$, $120.4,122.1,124.78,124.75,129.0,129.1,129.5,134.2,146.0$, 146.3, 148.8, 153.0, 161.8; IR (Nujol mull) 2225, 2196, 1668, 1650, 1610, 1600, 1578, 1567. Anal. Calcd for $\mathrm{C}_{20} \mathrm{H}_{12} \mathrm{~N}_{4} \mathrm{O}_{2}$ : C, 70.59; H, 3.53; N, 16.47. Found: C, 70.24; H, 3.61; N, 16.57.

Synthesis of 2-Amino-8-methoxy-4[(3-cyano-2H-chromen-2ylidene)amino]-2H-chromene-3-carbonitrile $8 \mathrm{~b}$.<smiles>COc1cccc2c1OC1=NC3(C(=O)C1=C2)C(C#N)=C(N)Oc1c(OC)cccc13</smiles>

Malononitrile $(0.26 \mathrm{~g}, 3.96 \mathrm{mmol})$ was added to a solution of 3-methoxysalicylaldehyde $(0.62 \mathrm{~g}, 4.05 \mathrm{mmol})$ in methanol $(6 \mathrm{~mL})$. Triethylamine ( 2 drops) was added to the reaction mixture, and the orange solution was stirred at room temperature for $6 \mathrm{~h}$. The yellow solid, which gradually precipitated from the reaction mixture, was filtered and washed with diethyl ether. The product $(0.57 \mathrm{~g})$ was identified as a mixture where the 2-iminochromene $\mathbf{1 b}$ and the dimer $\mathbf{8 b}$ were the major components, present in a 2:1 ratio. This solid was solubilized in DMSO $(2.5 \mathrm{~mL})$, and the dark red solution was stirred at room temperature. After $2 \mathrm{~h}$, a yellow solid started to precipitate from the solution, which was stirred at room temperature for 21 days.

The thick suspension was filtered, and the pale yellow solid was washed with diethyl ether and dichloromethane. The product was identified as the title compound $\mathbf{8 b}(0.50 \mathrm{~g}, 1.25 \mathrm{mmol}, 63 \%)$ : $\mathrm{mp}$ $150-152{ }^{\circ} \mathrm{C} ;{ }^{1} \mathrm{H}$ NMR $\left(300 \mathrm{MHz}\right.$, DMSO- $\left.d_{6}\right) \delta 3.83$ (s, 3H), 3.93 $(\mathrm{s}, 3 \mathrm{H}), 5.85(\mathrm{~s}, 1 \mathrm{H}), 6,92(\mathrm{dd}, J=7.4 \mathrm{~Hz}, 1.8 \mathrm{~Hz}, 1 \mathrm{H}), 7.00-$ $7.10(\mathrm{~m}, 2 \mathrm{H}), 7.15-7.20(\mathrm{~m}, 3 \mathrm{H}), 7.25(\mathrm{t}, J=8,2 \mathrm{~Hz}, 1 \mathrm{H}), 7.38$ $(\mathrm{dd}, J=8.2 \mathrm{~Hz}, 1.5 \mathrm{~Hz}, 1 \mathrm{H}), 8.36(\mathrm{~s}, 1 \mathrm{H}) ;{ }^{13} \mathrm{C}$ NMR $(75 \mathrm{MHz}$, DMSO- $\left.d_{6}\right) \delta 48.6,55.0,56.6,55.8,104.6,111.7,114.9,117.2$, $117.8,118.0,120.3,120.6,119.6,124.62,124.63,138.3,142.1$, 145.5, 146.5, 146.7, 147.0, 161.5; IR (Nujol mull) 2227, 2189, 1642, 1602, 1585. Anal. Calcd for $\mathrm{C}_{22} \mathrm{H}_{16} \mathrm{~N}_{4} \mathrm{O}_{4} \mathrm{C}_{2} \mathrm{H}_{6} \mathrm{SO} .0 .5 \mathrm{H}_{2} \mathrm{O}:$ C, 59.14; H, 4.72; N, 11.50. Found: C, 59.36; H, 4.86; N, 11.54.

Synthesis of 4,4'-(Cyanomethylylidene)bis(2-amino-8-methoxy-4H-chromene-3-carbonitrile) 9.<smiles>COc1cccc2c1OC(N)=C(N)C2=C(C#N)C1C(C#N)=C(N)Oc2c(OC)cccc21</smiles>

Method A. Triethylamine $(0.5 \mathrm{~mL})$ was added to a yellow suspension of 2-imino-8-methoxy-2H-chromene-3-carbonitrile $\mathbf{1 b}$ $(0.10 \mathrm{~g}, 0.51 \mathrm{mmol})$ in water $(6 \mathrm{~mL})$. The mixture turned orange after the addition of triethylamine and was stirred at room temperature. After $2.5 \mathrm{~h}$, methanol $(1 \mathrm{~mL})$ was added to the suspension to promote partial solubilization of the starting chromene. The beige solid was filtered and washed with water and then with diethyl ether, after $17.5 \mathrm{~h}$, leading to product $9(0.04 \mathrm{~g}, 0.10 \mathrm{mmol}$, $40 \%)$.

Method B. (2-Amino-3-cyano-8-methoxy-4H-chromene-4-yl)malononitrile $2 \mathbf{b}(0.16 \mathrm{~g}, 0.44 \mathrm{mmol})$ was added to an orange suspension of 2-imino-8-methoxy- $2 \mathrm{H}$-chromene-3-carbonitrile $\mathbf{1 b}$ $(0.08 \mathrm{~g}, 0.42 \mathrm{mmol})$ in aqueous $\mathrm{NaOH}(1 \mathrm{M}, 0.8 \mathrm{~mL})$. The reaction mixture was stirred at room temperature for $16 \mathrm{~h}$, and the yellow solid was filtered and washed with water and then with diethyl ether, leading to product $9(0.14 \mathrm{~g}, 0.31 \mathrm{mmol}, 74 \%): \mathrm{mp}>300$ ${ }^{\circ} \mathrm{C}$; ${ }^{1} \mathrm{H}$ NMR $\left(300 \mathrm{MHz}, \mathrm{DMSO}-d_{6}\right) \delta 3.73$ (s, 3H), $3.76(\mathrm{~s}, 3 \mathrm{H})$, $4.04(\mathrm{~s}, 1 \mathrm{H}), 6.95(\mathrm{dd}, J=7.5 \mathrm{~Hz}, 1.5 \mathrm{~Hz}, 1 \mathrm{H}), 7.03(\mathrm{dd}, J=8.1$ $\mathrm{Hz}, 1.5 \mathrm{~Hz}, 1 \mathrm{H}), 7.10-7.40$ (m, 6H), 7.38 (s, 2H); ${ }^{13} \mathrm{C}$ NMR $(75$ $\left.\mathrm{MHz}, \mathrm{DMSO}-d_{6}\right) \delta 46.6,47.8,48.8,55.9,56.0,112.6,113.4,119.2$, $121.1,123.9,124.8,117.5,117.8,119.3,119.6,119.9,120.7,138.5$, 140.7, 146.9, 146.9, 161.9, 164.4; IR (Nujol mull) 2200, 2184, 1645, 1619, 1601, 1579. Anal. Calcd for $\mathrm{C}_{24} \mathrm{H}_{17} \mathrm{~N}_{5} \mathrm{O}_{4} 0.9 \mathrm{H}_{2} \mathrm{O}$ : C, 63.27; H, 4.28; N, 15.94. Found: C, 63.28; H, 4.01; N, 15.95.

Synthesis of 4-Amino-5-imino-2,7-dimethoxy-5H-cromeno[3,4-c]pyridine-1-carbonitrile 12 .

Method A. Triethylamine (1 drop) was added to a white suspension of (2-amino-3-cyano- $4 H$-chromene-4-yl)malononitrile 2 (0.10 g, $0.38 \mathrm{mmol})$ in methanol $(7 \mathrm{~mL})$. The mixture turned yellow and was stirred at $9{ }^{\circ} \mathrm{C}$. The pale orange solid precipitated gradually from the reaction mixture and was filtered and washed with diethyl ether, after 5 days. The product was identified as 4-amino-5-imino- 
<smiles>COc1nc(N)c2c(=N)oc3c(OC)cccc3c2c1C#N</smiles>

2,7-dimethoxy-5H-cromeno[3,4-c]pyridine-1-carbonitrile 12 (0.029 $\mathrm{g}, 0.098 \mathrm{mmol}, 26 \%$ ).

The evolution of compound $\mathbf{1 2}$ in the NMR tube was followed for 12 days, and the final product was identified as 2-amino-4-(2hydroxy-3-mehoxyphenyl)-6-methoxypyridine-3,5-dicarbonitrile (15): ${ }^{1} \mathrm{H}$ NMR $\left(300 \mathrm{MHz}, \mathrm{DMSO}-d_{6}\right) \delta 3.85(\mathrm{~s}, 3 \mathrm{H}), 3.95(\mathrm{~s}, 3 \mathrm{H})$, $6.76(\mathrm{dd}, J=7.8 \mathrm{~Hz}, 1.5 \mathrm{~Hz}, 1 \mathrm{H}), 6.89$ (t, $J=8.1 \mathrm{~Hz}, 1 \mathrm{H}), 7.08$ (dd, $J=8.1 \mathrm{~Hz}, 1.2 \mathrm{~Hz}, 1 \mathrm{H}), 7.86$ (brs, $2 \mathrm{H}$ ), 9.24 (brs, $1 \mathrm{H}) ;{ }^{13} \mathrm{C}$ NMR (75 MHz, DMSO- $\left.d_{6}\right) \delta 54.7,55.8,113.0,115.0,115.3,119.2$, $120.7,121.7,143.4,147.7,159.0,161.0,165.6$. The signals for the two carbons attached to the cyano groups are not visible in the ${ }^{13} \mathrm{C}$ NMR spectrum.

Method B. Triethylamine (1drop) was added to a white suspension of (2-amino-3-cyano-4H-chromene-4-yl)malononitrile (2) $(0.10 \mathrm{~g}, 0.38 \mathrm{mmol})$ in methanol $(7 \mathrm{~mL})$. The mixture turned yellow and was refluxed. The starting material solubilized after 2-3 min, and after $10 \mathrm{~min}$, a yellow-greenish solid started to precipitate from the reaction mixture. After $3.5 \mathrm{~h}$, the suspension was cooled to room temperature. The yellow-greenish solid was filtered and washed with diethyl ether and identified as 4-amino-5-imino-2,7-dimethoxy-5 $\mathrm{H}$-cromeno[3,4-c]pyridine-1-carbonitrile $12(0.038 \mathrm{~g}, 0.13 \mathrm{mmol}, 34 \%): \mathrm{mp}>300{ }^{\circ} \mathrm{C} ;{ }^{1} \mathrm{H}$ NMR $\left(300 \mathrm{MHz}, \mathrm{DMSO}-d_{6}\right) \delta 3.85(\mathrm{~s}, 3 \mathrm{H}), 3.94(\mathrm{~s}, 3 \mathrm{H}), 7.16(\mathrm{t}, J=$ $8.1 \mathrm{~Hz}, 1 \mathrm{H}), 7.25$ (dd, $J=8.1 \mathrm{~Hz}, 1.2 \mathrm{~Hz}, 1 \mathrm{H}), 8.34$ (dd, $J=8.2$ $\mathrm{Hz}, 1.2 \mathrm{~Hz}, 1 \mathrm{H}), 8.40$ (d, $J=4.2 \mathrm{~Hz}, 1 \mathrm{H}), 8.74(\mathrm{~s}, 1 \mathrm{H}), 10.42(\mathrm{~d}$, $J=4.2 \mathrm{~Hz}, 1 \mathrm{H}) ;{ }^{13} \mathrm{C}$ NMR $\left(75 \mathrm{MHz}, \mathrm{DMSO}-d_{6}\right) \delta 54.9,55.9$, 74.8, 94.4, 115.3, 115.9, 116.1, 117.6, 123.1, 141.5, 144.3, 146.9, 154.4, 159.9, 166.7; IR (Nujol mull) 2217, 1640, 1603, 1566, 1542. HRMS m/z (FAB) calcd for $\mathrm{C}_{15} \mathrm{H}_{12} \mathrm{~N}_{4} \mathrm{O}_{3}(\mathrm{M}+\mathrm{H})^{+} 297.0988$, found 297.0988.

General Procedure for the Synthesis of Substituted (4,5Diamino-1-cyano-1,10b-dihydro-2H-chromeno[3,4-c]pyridin-2ylidene)malononitrile 13.

Malononitrile (1 molar equiv) was added to a solution of (2-amino3-cyano- $4 H$-chromene-4-yl)malononitrile $\mathbf{2}$ in THF. This mixture was refluxed for 3.5 days (2b) or 2 days (2c), and the solid started to precipitate after $24 \mathrm{~h}$. The suspension was cooled to room<smiles>[R]c1cccc2c1OC(N)=C1C(N)=NC(=C(C#N)C#N)[C@H](C#N)[C@H]12</smiles>

temperature $(13 b)$ and the orange $(13 b)$ or pink $(13 c)$ solid was filtered (at $\mathrm{rt}$ or from the hot reaction mixture) and washed with THF, leading to product 13.

(4,5-Diamino-1-cyano-7-methoxy-1,10b-dihydro-2H-chromeno[3,4-c]pyridin-2-ylidene)malononitrile 13b: orange solid; yield $56 \%$; mp $>300{ }^{\circ} \mathrm{C} ;{ }^{1} \mathrm{H}$ NMR $\left(300 \mathrm{MHz}, \mathrm{DMSO}-d_{6}\right) \delta 3.84(\mathrm{~s}$, $3 \mathrm{H}), 4.83(\mathrm{~d}, J=4.1 \mathrm{~Hz}, 1 \mathrm{H}), 4.91(\mathrm{~d}, J=4.1 \mathrm{~Hz}, 1 \mathrm{H}), 6.66$ (brs, $2 \mathrm{H}), 7.00(\mathrm{dd}, J=7.5 \mathrm{~Hz}, 1.5 \mathrm{~Hz}, 1 \mathrm{H}), 7.05$ (brs, $2 \mathrm{H}), 7.12$ (dd, $J=8.4 \mathrm{~Hz}, 1.5 \mathrm{~Hz}, 1 \mathrm{H}), 7.18(\mathrm{t}, J=8.1 \mathrm{~Hz}, 1 \mathrm{H}) ;{ }^{13} \mathrm{C} \mathrm{NMR}(75$ $\left.\mathrm{MHz}, \mathrm{DMSO}-d_{6}\right) \delta 30.3,34.8,70.5,118.6,141.0,157.0,160.4$ (2C), 83.7, 112.9, 113.4, 116.3, 147.7, 112.7, 124.0, 120.0, 55.8; IR (Nujol mull) 2253, 2198, 1644, 1599, 1561. Anal. Calcd for $\mathrm{C}_{17} \mathrm{H}_{12} \mathrm{~N}_{6} \mathrm{O}_{2} 0.3 \mathrm{H}_{2} \mathrm{O}$ : C, 60.46; H, 3.73; N, 22.49. Found: C, 60.49; $\mathrm{H}, 3.74 ; \mathrm{N}, 22.79$.

(4,5-Diamino-1-cyano-7-hydroxy-1,10b-dihydro-2H-chromeno[3,4-c]pyridin-2-ylidene)malononitrile 13c: pink solid; yield $86 \%$; $\mathrm{mp}>300{ }^{\circ} \mathrm{C}$; ${ }^{1} \mathrm{H}$ NMR $\left(300 \mathrm{MHz}\right.$, DMSO- $\left.d_{6}\right) \delta 4.81(\mathrm{~d}, J=4.1$ $\mathrm{Hz}, 1 \mathrm{H}), 4.88(\mathrm{~d}, J=4.1 \mathrm{~Hz}, 1 \mathrm{H}), 6.02$ (brs, $2 \mathrm{H}), 6.82(\mathrm{dd}, J=$ $7.05 \mathrm{~Hz}, 0.9 \mathrm{~Hz}, 1 \mathrm{H}), 6.92$ (dd, $J=7.8 \mathrm{~Hz}, 1.2 \mathrm{~Hz}, 1 \mathrm{H}), 7.00$ (t, $J=7.8 \mathrm{~Hz}, 1 \mathrm{H}), 7.03(\mathrm{sl}, 2 \mathrm{H}), 9.85(\mathrm{~s}, 1 \mathrm{H}) ;{ }^{13} \mathrm{C}$ NMR $(75 \mathrm{MHz}$, DMSO- $\left.d_{6}\right) \delta 30.4,34.8,70.5,83.9,113.0,113.5,116.4,116.7$, 118.6, 119.0, 123.9, 140.2, 145.7, 156.9, 160.3 (2C); IR (Nujol mull) 2254, 2198, 1644, 1599, 1561; HRMS $\mathrm{m} / \mathrm{z}$ (FAB) calcd for $\mathrm{C}_{16} \mathrm{H}_{10} \mathrm{~N}_{6} \mathrm{O}_{2}(\mathrm{M}+\mathrm{H})^{+}$319.0943, found 319.0947.

Acknowledgment. We gratefully acknowledge financial support from the University of Minho and Fundação para a Ciência e Tecnologia (project PRAXIS/C/QUI/45391/2002) and the Ph.D. grants awarded to M.C. (SFRH/BD/31531/2006) and L.A. (SFRH/BD/11228/2002).

Supporting Information Available: Full compound characterization data and copies of ${ }^{1} \mathrm{H}$ and ${ }^{13} \mathrm{C}$ NMR spectra for all new compounds. This material is available free of charge via the Internet at http://pubs.acs.org.

JO702552F 